НАУКОВИЙ ВІСНИК

Scientific messenger of Lviv National University of
Veterinary Medicine and Biotechnologies

(1)

$\sqrt{5}$

$\int=\underline{2}$

CEP९я: BETEPUHAPHI HAYK

Том 23 № 104

2021
Науковий вісник Аьвівського національного університету ветеринарної медицини та біотехнологій імені С.3. Гжицького. Серія: Ветеринарні науки

\author{
Scientific Messenger of Lviv National University \\ of Veterinary Medicine and Biotechnologies. \\ Series: Veterinary sciences
}

UDC 636.4.05.082.4/615.256.4-022.532.038/612.616.31

\title{
The peculiarities of hormonal background in boars under correction of reproductive capacity by gadolinium orthovanadate nanoparticles
}

\author{
V. I. Koshevoy ${ }^{1}$, S. V. Naumenko' ${ }^{1}$ V. K. Klochkov², S. L. Yefimova ${ }^{2}$ \\ ${ }^{1}$ State Biotechnological University, Kharkiv, Ukraine \\ ${ }^{2}$ Institute of Scintillation Materials of the National Academy of Sciences of Ukraine, Kharkiv, Ukraine
}

Article info

Received 29.09.2021

Received in revised form 28.10.2021

Accepted 29.10.2021

State Biotechnological University, Kharkiv, Alchevskykh Str., 44, 61002, Ukraine.

Tel.: +38-063-075-75-40

E-mail: vsevolod_koshevoy@yahoo.com

Institute of Scintillation Materials of the National Academy of Sciences of Ukraine,

Nauky ave. 60, Kharkiv,

61072, Ukraine.

Koshevoy, V. I., Naumenko, S. V., Klochkov, V. K., \& Yefimova, S. L. (2021). The peculiarities of hormonal background in boars under correction of reproductive capacity by gadolinium orthovanadate nanoparticles. Scientific Messenger of Lviv National University of Veterinary Medicine and Biotechnologies. Series: Veterinary sciences, 23(104), 66-70. doi: 10.32718/nvlvet10411

Determination of the influence of redox nanomaterials on the body of males is of great interest to researchers, because the basis of the pathogenesis of male infertility is oxidative stress. A necessary condition in the development of such drugs is the absence of toxic effects on sexual function. It has been proved that nanomaterials based on oxides of rare earth elements have a positive effect on reproductive capacity and, at the same time, they are not gonadotoxic. A comprehensive approach is of particular importance in order to justify their use as a means of reproductive capacity correction. Taking into account the toxicity parameters the mechanisms of their action need to be studied at the biochemical, morphological and clinical levels. The positive effect of gadolinium orthovanadate nanoparticles on the quality of boar sperm (especially in terms of motility and the number of motile sperm in the ejaculate) with an effective reduction of the oxidative load on the body have been shown. The aim of this study was to determine the effect of these nanoparticles on the hormonal background of males with a decreased reproductive capacity under oxidative stress. Thus, the administration of hydrosol of gadolinium orthovanadate nanoparticles for 14 days revealed a normalization of sex hormones - an increase in total testosterone, in particular, on the $15^{\text {th }}$ day of the study - by $22.6 \%$ $(P<0.01)$, and on the $30^{\text {th }}$ day - by $77.4 \%(P<0.001)$ compared with the group of animals before the administration. There was a decrease in the level of $17 \beta$-estradiol on the $30^{\text {th }}$ day - by $25.0 \%(P<0.01)$, which almost reached the values of the control group. A decrease in the content of globulin testosteroneestradiol-binding in boars of the experimental group, in particular, on the $15^{\text {th }}$ day of the experiment - by $13.0 \%(P<0.05)$, and on the $30^{\text {th }}$ day - by $26.8 \%(P<0.001)$ was determined, which, in turn, led to an increase in androgen saturation of the animal body - the index of free androgens at the end of the study was $43.2 \%$. The results are explained by the properties of the nanoparticles. Correcting oxidative stress, they increase the antioxidant potential, thereby normalizing the activity of endocrine glands and ways of regulating the germ-endocrine function of the gonads. The prospect of further research is to elucidate the effect of the correction of decreased reproductive capacity in boars under oxidative stress by nanoparticles of oxides of rare earth elements on the morphological state of the gonads.

Key words: nanomaterials, sex hormones, free androgen index, reproductive function.

\section{Introduction}

Actuality of the problem. There are many exogenous and endogenous factors that cause excessive synthesis of reactive oxygen species (ROS). Due to their excess over the antioxidant potential of cells oxidative stress (OS) occurs. In turn, OS adversely affects the reproductive function of males and leads to a partial-temporary decrease. It has a direct or indirect action on the hypotha- lamic-pituitary-gonadal axis (HPG) and/or disrupts its connection with other hormonal axes. If the imbalance between oxidants (ROS) and antioxidants predominates in the direction of oxidants, there is an OS that exposes cells and the body to stress. As a result, excessive amount of ROS can cause lipid peroxidation (LPO), destroy DNA, RNA, and disrupt the function of proteins in sperm and other gonadal cells (Wang et al., 2017; Darbandi et al., 2018; Rehman et al., 2020). 
It is known that ROS reduces the level of male sex hormones and disturbs the hormonal balance that regulates reproductive function (Appasamy et al., 2007; Olukole et al., 2020). OS resulting from increased ROS synthesis or decreased antioxidant availability can cause LPO in Leydig cells and germ cells, damage lipoproteins, aggregation and protein fragmentation, and inhibit steroidogenic enzymes (Wang et al., 2017).

Analysis of recent research and publications. ROS in the male reproductive system disrupts the balance between oxidants and antioxidants. After ROS generation the hypothalamic-pituitary-adrenal axis (HPA) is activated and releases corticosterone in response to stress. In response to the action of corticosterone between HPG and HPA there is an interaction that adversely affects the secretion of luteinizing hormone (LH) by the anterior pituitary gland. Decreased LH level is not able to stimulate Leydig cells to produce enough testosterone. Instead, a decrease in follicle-stimulating hormone reduces the release of androgen-binding protein (ABP) from Sertoli cells, and thus causes a decrease in testosterone level in the male body (Darbandi et al., 2018; Goma et al., 2020).

In addition, OS leads to a decrease in insulin secretion in the pancreas, which, in turn, has a negative effect on the release of T3 from the thyroid gland, and in general, on the biosynthesis of testosterone. Obesity-induced ROS synthesis affects adipocytes causing excessive leptin synthesis, which together with insulin reduces the release of T3 and, as a consequence, inhibits the functioning of the male gonads. Leptin produced by adipocytes also inhibits the release of gonadoliberins from the hypothalamus (Amjad et al., 2019; Khodamoradi et al., 2020; Turan \& Öztekin, 2020).

It is known that testicular estradiol and inhibin segregate intensively under OS, thereby inhibiting the release of testosterone. This is due to the effect of ROS on aromatase activity, which causes an increase in estradiol. Decreased testosterone levels cannot regulate spermatogenesis to produce full-fledged sperm. Such level is not able to maintain the functioning of additional gonads, which play an important role in sperm maturing. As the main regulator of the manifestation of sexual reflexes, testosterone causes them to slow down. Thus, impaired endocrine reproductive function leads to a decreased reproductive capacity in males (Makary et al., 2018; Sharma et al., 2021).

Contradictory data on the effectiveness of antioxidant therapy of male infertility by nanoparticles (NPs) of various chemical composition and their effect on the level of sex hormones and the morphological state of the gonads motivate researchers to seek effective and safe means. Thus, with the administration of NPs based on gold, silver and molybdenum, which are widely used in medical practice, the initiation of OS in gonads and pathological effect on their structural organization are observed. Instead, zinc oxide NPs caused an increase in sperm quality, sex hormone content and normalization of antioxidant potential (Asadi et al., 2017; Barati et al., 2020; Goma et al., 2020; Liu et al., 2020; Olugbodi et al., 2020).

Aim of the study was to evaluate the effect of gadolinium orthovanadate nanoparticles on the hormonal back- ground of boars by correcting their reproductive capacity under oxidative stress.

Research objectives:

1. To determine the dynamics of the level of sex hormones in the blood serum of boars with a decreased reproductive capacity under oxidative stress and by the correction of gadolinium orthovanadate nanoparticles.

2. To establish the content of testosterone-estradiolbinding globulin and the index of free androgens as indicators of androgen saturation of boars by correcting their reproductive capacity with gadolinium orthovanadate nanoparticles.

\section{Material and methods}

The work was performed in the laboratories of the Department of Veterinary Reproductology at Kharkiv State Zooveterinary Academy (from 01.09.2021 - the Department of Veterinary Surgery and Reproductology of State Biotechnological University) and the Department of Nanostructured Materials named after Y. V. Malyukin at the Institute of Scintillation Materials of the National Academy of Sciences of Ukraine (Kharkiv).

All manipulations with animals were carried out in accordance with the European Convention for the protection of vertebrate animals used for experimental and scientific purposes (2006) and General ethical principles of animal experiments adopted by the First National Congress on Bioethics (Kyiv, Ukraine, 2001).

Groups of animals were formed according to the sperm quality indicators and the content of OS markers. They were divided into two groups. The sperm quality in males of the control group $(n=5)$ met the standards, and in the experimental group $(\mathrm{n}=5)$ it was reduced, especially in terms of sperm motility and the number of motile sperm in ejaculate. At the same time, intensification of peroxidation processes towards the content of OS markers in blood serum was noted (Koshevoy et al., 2021).

Nanoparticles (NPs) of oxides of rare earth elements synthesized at the Department of Nanostructured Materials at the Institute of Scintillation Materials of the National Academy of Sciences of Ukraine under the agreement on scientific and practical cooperation (№ 48 from 22.07.2020) were used to correct the OS. Males of the experimental group were orally administered the hydrosol of gadolinium orthovanadate NP activated by europium with a size of $25 \times 8 \mathrm{~nm}$ grain size at a dose of $0.0125 \mathrm{mg}$ per $\mathrm{kg}$ of live weight for 14 days. It has been studied that gadolinium orthovanadate NP belong to the toxicity class IV - low-toxic compounds, that makes it possible to use them in biomedical studies (Koreneva et al., 2016).

Blood for research was taken according to the generally accepted method on the $1^{\text {st }}, 15^{\text {th }}$ and $30^{\text {th }}$ day of the experiment. To establish the dynamics of changes in hormonal background, the level of sex hormones in the blood serum - total testosterone and $17 \beta$-estradiol and the content of testosterone-estradiol-binding globulin (TEBG) was assessed by immunochemiluminescence. The free androgen index (FAI) was calculated from the obtained data. For this purpose, the amount of total testosterone in 
blood serum was divided by the content of TEBG. The obtained value was expressed in percentages.

All digital data obtained during the study were processed statistically using Microsoft EXCEL. Student's criterion was used to determine the probability of differences between mean values.

\section{Results and discussion}

The hormonal background in boars of the experimental group - with reduced reproductive capacity was characterized by a decrease in sex hormones. Thus, the level of total testosterone before the administration of NPs was lower by $49.7 \%(\mathrm{P}<0.001)$ of the control group, and the level of $17 \beta$-estradiol - by $47.7 \%(\mathrm{P}<0.001)$, which is shown in table 1 .

\section{Table 1}

Dynamics of hormonal background in boars with the introduction of gadolinium orthovanadate nanoparticles $(\mathrm{M} \pm \mathrm{m}$, $\mathrm{n}=5$ )

\begin{tabular}{|c|c|c|c|c|c|}
\hline \multirow{3}{*}{ № } & \multirow{3}{*}{ Indicator } & \multicolumn{4}{|c|}{ Groups of animals } \\
\hline & & \multirow{2}{*}{ Control } & \multicolumn{3}{|c|}{ Experimental } \\
\hline & & & Before administration & $15^{\text {th }}$ day & $30^{\text {th }}$ day \\
\hline 1 & Total testosterone level, $\mathrm{nmol} / \mathrm{l}$ & $16.7 \pm 0.52$ & $8.4 \pm 0.33^{* * *}$ & $10.3 \pm 0.31 * * * 1$ & $14.9 \pm 0.44 * 2$ \\
\hline 2 & The level of $17 \beta$-estradiol, nmol/1 & $1.3 \pm 0.05$ & $1.92 \pm 0.08 * * *$ & $1.71 \pm 0.07 * *$ & $1.44 \pm 0.06^{1}$ \\
\hline
\end{tabular}

The content dynamics of testosterone-estradiolbinding globulin (TEBG) and the index of free androgens (FAI) in boars with the administration of gadolinium orthovanadate nanoparticles is shown in Fig. 1. Thus, in boars of the experimental group before the administration of NPs an increase in the content of TEBG by $38.9 \%$ $(\mathrm{P}<0.001)$ compared with animals of the control group was determined. Taking into account the level of total testosterone and the amount of TEBG it can be proved that FAI in this group of animals was $49.3 \%$.

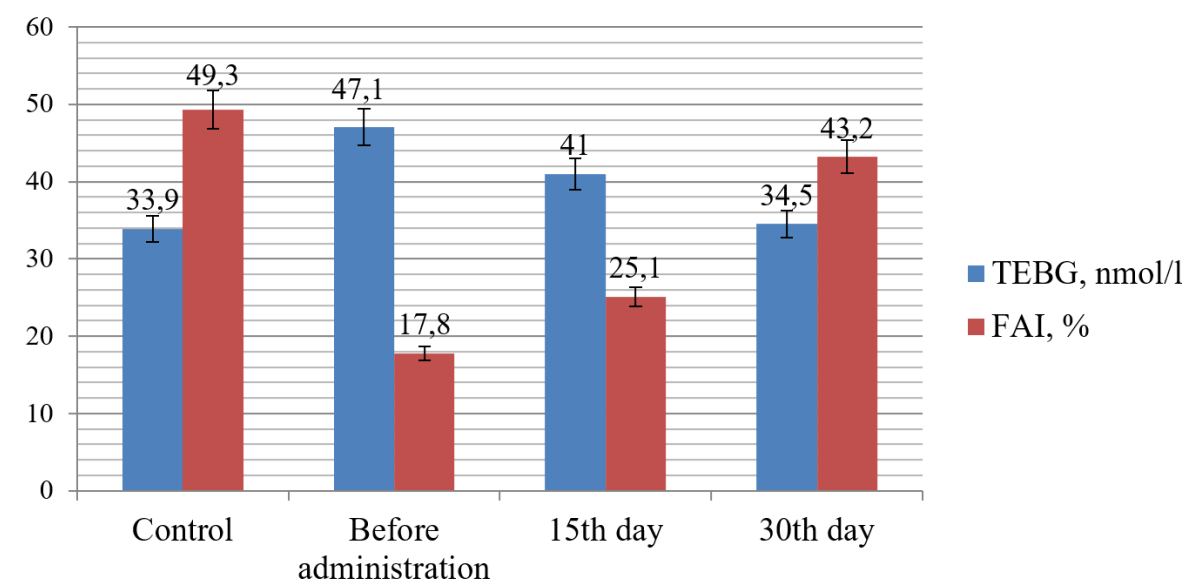

Fig. 1. Dynamics of the content of testosterone-estradiol-binding globulin and free androgen index in boars with the administration of gadolinium orthovanadate nanoparticles $(M \pm m, n=5)$

The administration of the hydrosol of gadolinium orthovanadate NPs contributed to the normalization of the hormonal background in boars of the experimental group. Thus, on the $15^{\text {th }}$ day of the experiment we observed an increase in the level of total testosterone in the blood serum of males by $22.6 \%(\mathrm{P}<0.01)$, instead, the level of $17 \beta$-estradiol tended to decrease. At the same time, a decrease in the content of TEBG by $13.0 \%(\mathrm{P}<0.05)$ was found, which, in turn, contributed to the increase of FAI to $25.1 \%$.

Restoration of hormonal background values in animals with full reproductive capacity occurred on the $30^{\text {th }}$ day of the experiment - testosterone levels in boar blood serum increased by $77.4 \%(\mathrm{P}<0.001)$ compared with the group before the administration of NPs and almost reached the control group $(\mathrm{P}<0.05)$. On the contrary, there was a decrease in the indicators of $17 \beta$-estradiol level (by $25.0 \%, \mathrm{P}<0.01$ ) and the content of TEBG (by $26.8 \%$, $\mathrm{P}<0.001)$. The obtained data show that the FAI in the group of boars on the $30^{\text {th }}$ day of the experiment was $43.2 \%$, i.e. almost reached the normative values.

The obtained changes in animals of the experimental group before the administration of NPs are due to the influence of OS, which causes a decrease in testosterone synthesis due to the damage in Leydig cells damage and other endocrine structures such as the anterior pituitary (Turner et al., 2005; Wang et al., 2017). It may be associated with an increase in the number of immature forms of sperm due to the impact on the production of male sex hormones that correlate with spermatogenesis.

Systemic hormones (testosterone, estradiol) are able to regulate the antioxidant capacity of testicular cells. Ap- 
parently, some hormones such as testosterone have an antioxidant effect that protects sperm and gonadal cells from the damage caused by ROS. There is a proven negative relationship between levels of testosterone, estradiol, free thyroxine in blood serum and DNA damage in sperm (Makary et al., 2018).

Thus, it was found that the administration of NPs helped to reduce the oxidative load on the body and restore sperm quality (Koshevoy et al., 2021). Our research results show that the administration of gadolinium orthovanadate NP causes the restoration of hormonal activity of the testes and other endocrine glands. This is due to their high redox activity and antioxidant properties shown in Wistar rats (Nikitchenko et al., 2021a; 2021b). Similar results have been reported by researchers using alternative antioxidant therapies for male infertility, such as NPs of zinc oxide, melatotin or coenzyme $\mathrm{Q}_{10}$ (Banihani, 2018; Obembe, 2019; Goma et al., 2020; Zhao et al., 2021).

\section{Conclusions}

The positive influence of the correction method of reproductive ability in boars by gadolinium orthovanadate nanoparticles on the hormonal balance of the body is proved:

1. With the administration of gadolinium orthovanadate NPs normalization of sex hormones - an increase in total testosterone, in particular, on the $15^{\text {th }}$ day of the study - by $22.6 \%$, and on the $30^{\text {th }}$ day - by $77.4 \%$ compared to the group of animals before administration was determined. In turn, there was a decrease in the level of $17 \beta$-estradiol on the $30^{\text {th }}$ day - by $25.0 \%$, which almost reached the values of the control group.

2. There was a decrease in the content of TEBG in boars of the experimental group, in particular, on the $15^{\text {th }}$ day of the experiment - by $13.0 \%$, and on the $30^{\text {th }}$ day by $26.8 \%$, which, in turn, led to an increase in androgenic saturation of the body of animals - FAI at the end of the study was $43.2 \%$.

The prospect of further research is to elucidate the influence of the correction of the decreased reproductive capacity in boars under oxidative stress by gadolinium orthovanadate NPs on the morphological state of the gonads.

\section{Conflict of interest}

The authors declare that there is no conflict of interest.

\section{References}

Amjad, S., Baig, M., Zahid, N., Tariq, S., \& Rehman, R. (2019). Association between leptin, obesity, hormonal interplay and male infertility. Andrologia, 51(1), e13147. doi: 10.1111/and.13147.

Appasamy, M., Muttukrishna, S., Pizzey, A. R., Ozturk, O., Groome, N. P., Serhal, P., \& Jauniaux, E. (2007). Relationship between male reproductive hormones, sperm DNA damage and markers of oxidative stress in infertility. Reproductive biomedicine online, 14(2), 159-165. doi: 10.1016/s1472-6483(10)60783-3.
Asadi, F., Mohseni, M., Dadashi Noshahr, K., Soleymani, F. H., Jalilvand, A., \& Heidari, A. (2017). Effect of Molybdenum nanoparticles on blood cells, liver enzymes and sexual hormones in male rats. Biological trace element research, 175(1), 50-56. doi: 10.1007/s12011-016-07655.

Banihani, S. A. (2018). Effect of Coenzyme Q 10 supplementation on testosterone. Biomolecules, 8(4), 172. doi: 10.3390/biom8040172.

Barati, E., Nikzad, H., \& Karimian, M. (2020). Oxidative stress and male infertility: current khowledge of pathophysiology and role of antioxidant therapy in disease management. Cellular and molecular life scienes: CMLS, 77(1), 93-113. doi: 10.1007/s00018-019-03253-8.

Darbandi, M., Darbandi, S., Agarwal, A., Sengupta, P., Durairajanayagam, D., Henkel, R., \& Sadeghi, M. R. (2018). Reactive oxygen species and male reproductive hormones. Reproductive biology and endocrinology: RB\&E, 16(1), 87. doi: 10.1186/s12958-018-0406-2.

Goma, A. A., Tohamy, H. G., El-Kazaz, S. E., Soliman, M. M., Shukry, M., Elgazzar, A. M., \& Rashed, R. R. (2020). Insight study on comparison between zinc oxide nanoparticles and its bulk impact on reproductive performance, antioxidant levels, gene expression, and histopathology of testes in male rats. Antioxidants (Basel, Switzerland), 10(1), 41. doi: 10.3390/antiox10010041.

Khodamoradi, K., Parmar, M., Khosravizadeh, Z., Kuchakulla, M., Manoharan, M., \& Arora, H. (2020). The role of leptin and obesity on male infertility. Current opinion in urology, 30(3), 334-339. doi: 10.1097/MOU.0000000000000762.

Koreneva, E. M., Karpenko, N. A., Smolenko, N. P., Belkina, I. O., Chistyakova, E. Ye., Selyukova, N. Y., Karachentsev, Yu. I., Klochkov, V. K., Yefimova, S. L., \& Kavok, N. S. (2016). Vplyv nanochastynok ortovanadatu hadoliniiu ta dioksydu tseriiu na spermohramu doroslykh samtsiv shchuriv iz neonatalno indukovanymy rozladamy reproduktyvnoi funktsii [The influence of gadolinium orthovanadate and cerium dioxide nanoparticles on spermogram of adult male rats with neonatal induced disorders of reproductive function]. Problemy Endokrynnoi Patolohii, 1, 48-55 (in Ukrainian).

Koshevoy, V. I., Naumenko, S. V., Klochkov, V. K., \& Yefimova S. L. (2021). The use of gadolinium orthovanadate nanoparticles for the correction of reproductive ability in boars under oxidative stress. Ukrainian journal of veterinary sciences, 2, 74-82. doi: 10.31548/ujvs.2021.02.008.

Liu, Y., Li, X., Xiao, S., Liu, X., Chen, X., Xia, Q., Lei, S., Li, H., Zhong, Z., \& Xiao, K. (2020). The effects of gold nanoparticles on Leydig cells and male reproductive fucnction in mice. International journal of nanomedecine, 15, 9499-9514. doi: 10.2147/IJN.S276606.

Makary, S., Abdo, M., \& Fekry, E. (2018). Oxidative stress burden inhibits spermatogenesis in adult male rats: testosterone protective effect. Canadian journal of physiology and pharmacology, 96(4), 372-381. doi: 10.1139/cjpp-2017-0459.

Nikitchenko, Y. V., Klochkov, V. K., Kavok, N. S., Averchenko, K. A., Karpenko, N. A., Nikitchenko, I. V., 
Yefimova, S. L., \& Bozhkov, A. I. (2021a). Anti-aging effects of antioxidant rare-earth orthovanadate nanoparticles in Wistar rats. Biological trace element research, 199(11), 4183-4192. doi: 10.1007/s12011-020-02531-y.

Nikitchenko, Y. V., Klochkov, V. K., Kavok, N. S., Karpenko, N. A., Yefimova, S. L., Nikitchenko, I. V., \& Bozhkov, A. I. (2021b). Age-related effects of orthovanadate nanoparticles involve activation of GSHdependent antioxidant system in liver mitochondria. Biological trace element research, 199(5), 649-659. doi: 10.1007/s12011-020-02196-7.

Obembe, O. O. (2019). Sex hormones and oxidative stress biomarkers of male Wistar rats treated with Moringa oleifera seed fractions. JBRA assisted reproduction, 23(4), 408-413. doi: 10.5935/1518-0557.20190047.

Olugbodi, J. O., David, O., Oketa, E. N., Lawal, B., Okoli, B. J., \& Mtunzi, F. (2020). Silver nanoparticles stimulates spermatogenesis impairments and hematological alterations in testis and epididymis of male rats. Molecules (Basel, Switzerland), 25(5), 1063. doi: 10.3390/molecules25051063.

Olukole, S. G., Ola-Davies, E. O., Lanipekun, D. O., \& Oke, B. O. (2020). Chronic exposure of adult male Wistar rats to bisphenol A causes testicular oxidative stress: role of gallic acid. Endocrine regulations, 54(1), 14-21. doi: 10.2478/enr-2020-0003.
Rehman, R., Amjad, S., Tariq, H., Zahid, N.. Akhter, M., \& Ashraf, M. (2020). Oxidative stress and male infertility: a cross sectional study. JPMA. The Journal of the Pakistan Medical Association, 70(3), 461-466. doi: 10.5455/JPMA.12992.

Sharma, A., Minhas, S., Dhillo, W. S., \& Jayasena, C. N. (2021). Male infertility due to testicular disorders. The Journal of clinical endocrinology and metabolism, 106(2), 442-459. doi: 10.1210/clinem/dgaa781.

Turan, E., \& Öztekin, U. (2020). Relationship between visceral adiposity index and male infertility. Andrologia, 52(4), e13548. doi: 10.1111/and.13548.

Turner, T. T., Bang, H. J., \& Lysiak, J. J. (2005). Experimental testicular torsion: reperfusion blood flow and subsequent testicular venous plasma testosterone concentrations. Urology, 65(2), 390-394. doi: 10.1016/j.urology.2004.09.033.

Wang, Y., Chen, F., Ye, L., Zirkin, B., \& Chen, H. (2017). Steroidogenesis in Leydig cells: effects of aging and environmental factors. Reproduction (Cambridge, England), 154(4), 111-122. doi: 10.1530/REP17-0064.

Zhao, F., Whiting, S., Lambourne, S., Aitken, R. J., \& Sun, Y. P. (2021). Melatonin alleviates heat stressinduced oxidative stress and apoptosis in human spermatozoa. Free radical biology \& medicine, 164, 410-416. doi: 10.1016/j.freeradbiomed.2021.01.014. 